\title{
KENNETH HUDSON OCH HANS BÖCKER
}

Per-Uno Agren

Kenneth Hudson var en obegripligt produktiv forfattare. Boklistan här nedan aterges efter senaste numret av European Museum Forum Magazine (Summer 2000, Number 6), som är ägnat Kenneth Hudsons minne. Bibliografin omspänner ären 1951-1993 och förtecknar 63 titlar. De speglar hans breda kulturhistoriska intressen, där självklart hans bada specialomraden särskilt framträder - industriarkeologin och museerna. I bäda fallen finns en socialhistorisk inriktning: den nu publicerade föreläsningen fran 1992 Why every museum is really a museum of social history är härvidlag en sorts huvudnyckel till hans passion for museer. Hans språkliga intresse är också pafallande - se två titlar frän àren 1977, 1978 och inte mindre än tre fràn 1983. Det finns ocksà med i manga begreppsdiskussioner $i$ hans böcker, exempelvis när han diskuterar forståelsen av termen 'arkeologi' använd i kombinationen 'industrial archaeology'. Mera överraskande är möjligen de skrifter han ägnat könsrollsfrägor. Hans Men and Women... fran 1968 lär ha inspirerat Germain Greer till The Female Eunuch som utkom ett par ar senare.

Hans publicistiska flit var enastående. De textrika och informativa directories över museer som han åren 1975,1980 , $1981,1985,1987,1989$ och 1991 utgav tillsammans med Ann Nicholls är imponerande prestationer. Från 1968 till 1972 bar årligen två eller tre böcker hans författarnamn, åren 1975 till 1980 utgav han fyra böcker om året (med undantag av 1979 då fem böcker kom!). Utgivningstakten minskade småningom under 1980talet.

Ändå gör listan honom inte full rättvisa.
År 1964 tog han initiativet till och redigerade The Journal of Industrial Archaology. Från 1974 skrev och redigerade han de årliga publikationerna till utdelningarna av europeiska museiprisen, likaledes, från 1992, EMYAs Newsletter, som från 1994 ersattes av EMFs Magazine. Han har lämnat spår i många symposie- och konferenspublikationer, exempelvis i Museums 2000 utgiven av Patrick Boylan efter Museums Association's konferens 1989, där ett av Hudsons mest provokativa utfall mot favoritmålet konstmuseer återfinns. Han 
18 bidrog till tidskrifter som Museums Journal och så sent som 1999 finns en text av honom i ICOM Study Series 6. Uppräkningen kunde fortsätta, men det får räcka med att han under de senaste åren, då han hade svårt att röra sig, outtröttligt deltog i diskussionerna vid EMFs möten i form av 'video-talks', som finns tillgängliga på kassett.

\section{KENNETH HUDSON'S BOOKS}

1951 English Letter Writers. Exeter: Wheaton and Co.

1954 Shakespeare and the Classroom. With a foreword by Bernard Miles.

Heinemann.

1963 Industrial Archaeology: an Introduction. John Baker: Revised and reprinted 1966 .

1965 The Industrial Archaeology of Southern England. Newton Abbot: David \& Charles. Revised and reprinted 1968.

1967 An Awkward Size for a Town. Newton Abbot: David \& Charles.

1967 A Handbook for Industrial Archaeologists. John Baker.

1968 Towards Precision Shoemaking. Newton Abbot: David \& Charles.

1968 The History of English China Clays. Newton Abbot: David \& Charles.

1968 Men and Women: Feminism and Anti-Feminism Today. Newton Abbot: David and Charles.

1970 Working to Rule. Bath: Adams \& Dart.

1970 The Place of Women in Society. Ginn.
1971 The Fashionable Stone. Bath: Adams \& Dart.

1971 A Guide to the Industrial Archaeology of Europe. Bath: Adams \& Dart.

1971 Towards a Welfare State. Ginn.

1972 Building Materials. Longman.

1972 Air Travel: a Social History. Bath: Adams \& Dart.

1972 Patriotism with Profit: British Agricultural Societies in the 18th and 19 th centuries. Hugh Evelyn.

1973 Industrial Archaeologist's Guide. With Neil Cossons. Newton Abbot: David \& Charles.

1975 The Directory of Museums. With Ann Nicholls. Macmillan, 1st edition.

1975 Exploring our Industrial Past. Hodder and Stoughton.

1975 A Social History of Museums. Macmillan.

1975 The Industrial History of Europe. Japanese edition:Tokyo.

1976 The Bath and West. Bath: Adams and Dart.

1976 The Archaeology of Industry. The Bodley Head.

1976 A Pocket Book for Industrial Archaeologists. John Baker.

1976 The Businessman in Public. Associated Business Programmes.

1977 The People and Pleasures of Bath. Michael Joseph/The Folio Society.

1977 The Dictionary of Diseased English. Macmillan.

1977 The End of Gin and Tonic Man: a 
Future for Public Relations. Wilton House Publications.

1977 Museums for the 1980s: a Survey of World Trends. Macmillan/Unesco.

1978 Exploring Cathedrals. Hodder and Stoughton.

1978 Food, Clothes and Shelter. John Baker.

1978 The Jargon of the Professions. Macmillan.

1978 The Language of Modern Politics. Macmillan. Reprinted Papermac 1980.

1979 Street Furniture. The Bodley Head.

1979 Tragedy on the High Seas: a History of Shipwrecks. With Ann Nicholls.

New York: A. and W. Publishers.

1979 A History of Shipwrecks. With Ann Nicholls. Macmillan.

1979 World Industrial Archaeology. Cambridge University Press.

1979 Archeologia dell'Industria. Translated by Bruno Granada from The Archaeology of Industry (1976). Rome: Newton Compton.

1979 Diamonds in the Sky: a Social History of Air Travel. With Julian Pettifer. The Bodley Head, for BBC.

1980 Where We Used to Work. John Baker.

1980 The Good Museums Guide.

Macmillan. Revised and reprinted version 1982.

1980 The Shell Guide to Country Museums. Heinemann.

1980 Farm Furniture. The Bodley Head.

1981 The Directory of Museums. With Ann
Nicholls. Macmillan. 2nd edition.

1982 Waterside Furniture. The Bodley Head.

1982 Behind the High Street. The Bodley Head.

1982 Pawnbroking: an Aspect of British Social History. The Bodley Head.

1982 Help the Aged: Twenty-One Years of Experiment and Achievement. The Bodley Head.

1983 The Language of the Teenage Revolution. Macmillan.

1983 The Dictionary of the Teenage Revolution and its Aftermath. Macmillan.

1983 The Dictionary of Even More Diseased English. Mamillan.

1983 Industrial History from the Air. Cambridge University Press.

1984 Clues to Yesterday's Transport. The Bodley Head.

1984 Churchyards and Graveyards. The Bodley Head.

1985 The Directory of Museums and Living Displays. With Ann Nicholls.

Macmillan. 3rd edition.

1987 Museums of Influence. Cambridge University Press.

1987 The Cambridge Guide to the Museums of Britain and Ireland. With Ann Nicholls. Cambridge University Press. Revised, paperback edition 1989.

1989 The Cambridge Guide to the Historic Places of Britain and Ireland. With Ann Nicholls. Cambridge University Press. 
201990 1992: Prayer or Promise. The Opportunities for Britain's museums and the people who work in them. HMSO: for Museums and Galleries Commission.

1991 The Cambridge Guide to the Museums of Europe. With Ann Nicholls. Cambridge University Press.

1992 Museums: Treasures or Tools? Strasbourg: Council of Europe.

1993 New Museums in Europe 1997-93.

Edited by Massimo Negri. Text by Kenneth Hudson. Milan: Mazzotta.

\section{KENNETH HUDSONS UPPSATSER} I NORDISK MUSEOLOGI

\section{The Great European Museum.} 1993:2, s 51-60.

The wrong and the right way for museums. 1996:1, s 121-126. Svensk version av texten, Ett viktigt vägval, finns i Museet som makt och motständ, festskrift till Erik Hofrén 10 april 1996, s 161-166.

Ecomuseums become more realistic. 1996:2, s 11-19.

What I think of as my heritage. 1998:1, s 9-16.

Why every museum is really a museum of social history. 2000:1, s. xx-xx.

(Museums inside and outside the establishment. Uppsatsen finns tryckt i Papers in Museology 1, Umeå 1989.) 